\title{
Hydrogen Production by Membrane Water Splitting Technologies
}

\author{
Mohd Fadhzir Ahmad Kamaroddin, \\ Nordin Sabli and Tuan Amran Tuan Abdullah \\ Additional information is available at the end of the chapter
}

http://dx.doi.org/10.5772/intechopen.76727

\begin{abstract}
Hydrogen production by membrane water splitting technologies is a sustainable method to synthesize hydrogen and provides an alternative to hydrogen production instead of conventional process of synthesizing hydrogen from steam methane reforming. A hybrid polymer electrolyte membrane electrolyzer operational at working temperature of above $80-200^{\circ} \mathrm{C}$ is advantageous for faster electrochemical kinetics, higher current exchange density, and more resistance to fuel impurities. Phosphoric acid (PA) doping onto polybenzimidazole (PBI) membrane shows significant improvement in proton conductivities, permeability, and thermal stability. PBI-based electrolyzer is relatively new to the hydrogen production technologies as compared to Nafion-based electrolyzer. However, the high cost of purchasing Nafion membrane and inability to execute electrolysis operational above $90^{\circ} \mathrm{C}$ has sparked new interest on PBI-based membrane, which is known for its good thermal stability.
\end{abstract}

Keywords: hydrogen production, water splitting, polymer electrolyte membrane, electrolysis, sustainable

\section{Introduction}

Sustainable energy from renewable resources has become a focal point for many researchers around the world in their search to minimize the carbon emission released to the atmosphere. Hydrogen energy is the cleanest available energy, which only releases heat and water as byproducts. Moreover, hydrogen combustion contributes to zero carbon emission. The Kyoto Protocol tabled in 1997 that came into effect in 2005 aimed to reduce the greenhouse gases 
(GHG) by 5\% (2005-2012) and 18\% (2013-2020) against 1990 levels [1]. Unlike a conventional steam methane reforming process, the hybrid polymer electrolyte membrane (PEM) combines with copper (I) chloride and hydrochloric acid electrolytes that have a promising future of providing a sustainable hydrogen production.

Currently, there has been a crucial need for rapid changes from the hydrocarbon-based economy to the one with sustainable and renewable sources [2-4]. Many green technologies are available right now, such as the generation of hydrogen [5], solar electricity [6, 7], and other renewable energy technologies, but the capital expenditure to acquire this technology is very high as compared to conventional energy resources $[8,9]$. For example, solar energy is limited by the efficiency of the panel and battery, while the electric vehicle is limited by the lack of charging facility and unsustainable production of electricity generation from coal- and petroleum-based fuel. It has been reported by Nicoletti et al. and Ball and Weeda $[10,11]$ the by-products from the combustion of hydrocarbon-based fuels are the major factors to the phenomena like global warming, the thinning of the ozone layer, acid rains, and air pollution and its harmful effect on respiratory problems. This is where hydrogen as the vital energy carrier and fuel sources offers sustainable and clean energy for the future [10, 12, 13].

Hydrogen does not exist individually, but it formed water molecules $\left(\mathrm{H}_{2} \mathrm{O}\right)$ which contain single oxygen atom and dual hydrogen atom makes it an enormous amount of elements in the world. Hydrogen is able to generate sustainable, immaculate and cost-effective energy resources, which can uplift the economic activities of the world with environmentally friendly and secure energy. This is due to no carbon dioxide or carbon monoxide being produced in the process of combusting hydrogen with only water as by-products [14]. Hydrogen production can be synthesized from many types of resources like water, biomass, coal, methane, and others via chemical, thermal, and biological processes [15].

Hydrogen is also an important feedstock for chemical processes [16], and 97\% of the world hydrogen supply comes from hydrocarbon-based fuels via reforming process [17] with the world's production of 50 million tons of hydrogen every year [15]. Among the various hydrogen production technologies that are available, electrolysis plays a vital role in producing sustainable hydrogen $[18,19]$. Water electrolysis is also acknowledged as a crucial element in the forthcoming energy system [16]. Although this electrolysis technology was invented more than 100 years ago, the hydrogen production from water electrolysis is substantially more costly with the efficiency rate only $18-24 \%$ and mainly used when the high purity of hydrogen is needed or in a remote area where methane gas is not available. The cost of producing hydrogen from water electrolysis is more expensive because hydrogen does not exist as an independent gas but occurs naturally in the form of chemical compounds like the hydrocarbons and water $[11,20]$.

\section{Types of membranes for hydrogen production}

To date, there are few ways of synthesizing the ion exchange or polymer membranes including sulfonation, polymer blending, acid or base doping, addition of inorganic fillers, pores 
filling, in-situ polymerization, and electrospinning [21, 22]. High-performance polymer electrolyte membranes (PEMs) must have the following characteristics [22]:

a. high proton conductivity

b. good electrical insulation

c. high mechanical and thermal stability

d. good oxidative and hydrolytic stability

e. cost-effectiveness

f. low tolerance to ion crossover/good barrier property

g. low swelling stress

h. capability for fabrication of membrane electrode assemblies (MEA)

One of the most important characteristics of the proton exchange membranes is water uptake that influences the electrochemical activity and hydromechanical stability of the membrane. Certainly, water is the fundamental element for proton transfer mechanism from the anode to the cathode in an electrochemical cell including an operation using non-sulfonated membranes in almost anhydrous condition and at a temperature range of $90-160^{\circ} \mathrm{C}$ [23]. However, the mechanical strength for a membrane with a higher water uptake reduces due to exorbitant swelling of the membrane. As a matter of fact, sulfonated membranes absorb more water molecules per acid group $(\lambda)$ when compared with phosphonated membranes that make phosphonated membranes more favorable for PEM applications due to higher ionic exchange capacity (IEC) [24].

\subsection{Polymer electrolyte membrane}

Polymer electrolyte membrane usage in fuel cell technologies (PEM-FC) is widely accepted, and more advanced version of this PEM can significantly transform the energy security for probably 20-30 years from now. It has turned into an attractive research due to its advantages of generating minimum pollution, great power density, and excellent conversion. This is a promising path to be fossil fuel free and to contribute to other sustainable energy sources $[25,26]$.

Currently, perfluorosulfonic acid polymer membranes like Nafion is accepted as the most widely used applications for both PEM-FC and direct methanol fuel cell (DMFC) because of their superiority and exceptional performance in thermal stability, eminent ionic exchange capacity, and proton conductivity [26, 27]. However, the Nafion is costly, and it experiences huge methanol crossover for DMFC with the addition of depletion of proton conductivity when subjected to working temperature beyond $100^{\circ} \mathrm{C}$ [27]. Apart from isolating reactants from mixing together, PEM can allow proton to pass through while being nonelectrically conductive. Furthermore, PEMs have other functions of providing high ionic conductivity, good mechanical properties, and minimum to no ion crossover [28]. However, moderate operation 
temperature from 80 to $180^{\circ} \mathrm{C}$ for PEM fuel cells is ideal for heat co-generation. In addition, with current low-temperature operation, a huge capital expenditure is required for acquiring the commercial perfluorosulfonic acid (PFSA) membrane.

Major obstacles for the development of Direct Methanol Fuel Cell (DMFC), PEM-FC, Redox Flow Batteries (RFB) technologies, which have a high crossover of ion via the membrane can be improved and rectified with the use of low feed/water/electrolyte crossover [28]. Multiple approaches and new types of materials have been formulated to mitigate the problem but with serious concerns in the chemical stability and proton conductivity. The membrane ionic conductivity can be enhanced by means of doping with acids such as heteropoly acids (HPA) [28].

In fuel cell development, the PEM needs to have the following characteristics including excellent proton conductivity, favorable mechanical properties, exceptional resistance to chemicals, and durable enough for endurance testing [4]. Nafion-based PEM is used for low temperatures operation $<80^{\circ} \mathrm{C}$, while for higher temperature of $120-200^{\circ} \mathrm{C}$ hydrocarbon polymers like polybenzimidazole (PBI), sulfonated poly(arylene ether ether ketone) and poly (bis(phenoxy) phosphazene) are being used as described in the literature. Table 1 shows some of the proton exchange membranes that are manufactured by established organizations.

Currently, Nafion is used as a common membrane for solid polymer electrolyte although it has disadvantages for being expensive and a fluorinated-based polymer. Thus, recent studies are more focused on the improvement of cheaper and non-fluorinated polymers like polybenzimidazole (PBI), polyethersulfone (PES), sulfonated polysulfone (SPSF), polyaryleneethers, polyphosphazene, sulfonated polyetheretherketone (SPEEK), and polyimides. The advantages of these polymers are that they are cheaper and have good thermal, mechanical, and chemical properties. Out of these polymers, membranes from SPEEK polymer have demonstrated a very good performance for water electrolysis. The proton conductivity can be increased by adjusting the higher degree of sulfonation (DS) for SPEEK polymer due to its excellent mechanical properties. This will allow the optimization of DS onto the polymer

\begin{tabular}{ll}
\hline Organization & Type of membranes \\
\hline US Polyfuel Inc. & Acid-based polyether ether ketone \\
Toshiba & Acid-based polyether ether sulfone \\
Sony & OH-modified fullerene based membranes \\
JSR Corporation, Japan & Polystyrene sulfonic acid-based compounds \\
Stuttgart University, Germany & Acid-based ionomer blends \\
Los Alamos National Laboratory (LANL) & Sulfonation sulfone polymer; PVDF-g-SPS \\
Ballard & Sulfonated F-styrene \\
DuPont & Modified Nafion \\
Asahi Glass & PFS/PTFE fibrils \\
\hline
\end{tabular}

Table 1. Proton exchange membrane of established manufacturers [4]. 
membrane by manipulating the temperature and immersion time of the sulfonation reaction. The DS of the polymers can also be manipulated by varying the sulfonating agent concentration and the sulfonated monomers content. Furthermore, the sulfonic group $\left(-\mathrm{SO}_{3} \mathrm{H}\right)$ enhances the selectivity, solubility, and water uptake, which contributes to superior chemical properties $[29,30]$. Aromatic polymers that are exposed to high sulfonation (higher DS) will have a better proton conductivity. However, higher DS can lead the polymer to become more soluble and swell in water, thus decrease the mechanical strength of the membrane significantly. Therefore, the method used to improve the electrochemical and mechanical properties of the membrane is by forming a composite membrane using the addition of organic and inorganic compounds [29].

Generally, PEM fuel cell working temperature is limited by the Nafion membrane electrochemical properties, which can only operate at a temperature less than $100^{\circ} \mathrm{C}$. Although, the ideal working temperature of the PEM-FC based on Pt catalyst should be higher than $100^{\circ} \mathrm{C}$ as it can significantly mitigate the effect of $\mathrm{CO}$ poisoning [27]. Principally, fuel cell consumes oxygen and hydrogen gas to produce electricity, water, and heat as compared to an electrolyzer that produces hydrogen and oxygen as the products.

There are four types of polymer electrolytes for hydrogen economy, which includes fluorinated and partially fluorinated membranes, hydrocarbon membranes, aromatic membranes, and hybrid membranes.

The main polymer chain is used to categorize the type of polymer electrolytes. As a guideline, the primary chain indicates the surface morphology including physical and thermomechanical properties. Apart from that, the supporting chain contributes to the polymer functionality. Typical polymer chains consist of hydrocarbons, perfluorinated and aromatic, as their primary polymer chains. Majority of the polymers used in the research comprise sulfonic acid groups. It is located at supporting chains or as functional groups at the polymer backbone. The sulfonic group functions as a proton conductor in order to promote proton movement across the membrane [31].

\subsubsection{Proton exchange membrane}

In recent years, there has been an increasing amount of literature on proton exchange membrane particularly focusing on hydrogen production for fuel cells and electrolyzers. Di Noto et al. [32] reported that an excellent proton-conducting membrane for a fuel cell comprises the following attributes:

a. Exceptional stability on electrochemical and chemical properties

b. Great strength and stability on mechanical properties within process temperature limit

c. Membrane chemical properties are suitable for the membrane electrode assembly

d. Exceptionally very little reactant crossover

e. High water retention to maintain electrolyte species and avoid confined drying 
f. Superior conductivity of proton to brace high current with the lowest resistance deprivation and minor electronic conductivity

g. Cheap in producing the membrane

Proton Exchange Membrane (PEM) is commonly used in the fuel cells setup. The most popular and widely used PEM is Nafion and Nafion-based membrane because of its excellent proton conductivity and good physicochemical properties. However, Nafion experiences very distinct fuel crossover, tedious process to synthesize, and weak proton conductivity at high temperature in low humidity condition. There are many types of research being conducted to find the alternative membranes for fuel cell systems. Polymers like poly (ether ether ketone), poly (arylene ether ketone), and poly (ether sulfone) have been studied and tested as solid electrolytes in fuel cell applications. All of the studies conducted for PEEK, PAEK, and PES support the fact that aromatic polymer electrolytes are suitable and perform very well in fuel cell systems. The criteria include excellent proton conductivity, good thermomechanical and chemical properties, and reasonable cost. This material is also cheaper and easier to form a membrane as compared to Nafion membranes.

Therefore, the PEEK is chosen as an alternative to Nafion primarily because it is cheaper and easier to synthesize with good electrochemical and stable physicochemical properties [27].

\subsubsection{Nafion membrane}

General Electric Co. (USA) is the first to develop proton exchange membrane (PEM) electrolyzer back in 1966 from a solid polymer electrolyte, which comprises of membrane, anode, and cathode. Nafion membrane produced by DuPont is the most well-known membrane that is made up of perfluorinated polymer with sulfonic acid functionalization as depicted in Figure 1 [33].

Majority of the available PEM-FC are using proton exchange membranes that originate from perfluorosulfonic acid (PFSA) polymers such as Nafion 115, Nafion 117, and Nafion 212. Nafion has a very good chemical resistance, good mechanical properties, and are very durable [35]. Apart from that, Nafion shows good stability when subjected to radical degradation and

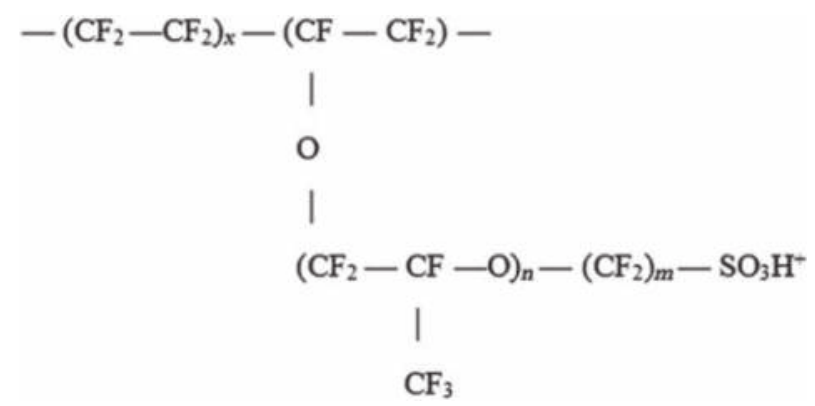

Figure 1. The structural formula of Nafion ${ }^{\circledR}$ membrane by DuPont de Nemours [34]. 
peroxide ions [36]. Despite all the advantages, Nafion also has few disadvantages such as they cannot function smoothly under dehydrated ambiance and cannot withstand higher operating temperature above $80^{\circ} \mathrm{C}$ ( $1 \mathrm{~atm}$ pressure) as it will deteriorate its good proton conductivity performance [35]. Moreover, Nafion is not suitable for temperature conditions below $0^{\circ} \mathrm{C}$ or beyond $100^{\circ} \mathrm{C}$, and its proton conductivity is water dependent [36].

Nafion and perfluorinated membranes are considered as the benchmark for other new membrane synthesis [32]. There is also a study being carried out on the modification of Nafionbased membrane with polyaniline (PANI) by varying the membrane thickness. The physical properties such as ion exchange capacity (IEC), proton conductivity, and water uptake are investigated. Moreover, the $\mathrm{Cu}$ permeability or $\mathrm{Cu}$ crossover phenomena was studied using an ex situ $\mathrm{Cu}$ diffusion cell and the performance of the modified membrane was configured using a $\mathrm{CuCl}$ electrolytic system [37].

Perfluorosulfonic acid (PFSA) polymer electrolyte membrane conductivity and hydration properties can be enhanced by synthesizing composite membranes with organic fillers such as hygroscopic oxides $\left(\mathrm{SiO}_{2} / \mathrm{TiO}_{2}\right)$, zirconium phosphates $\left.\mathrm{Zr}\left(\mathrm{HPO}_{4}\right)_{2} \cdot \mathrm{nH}_{2} \mathrm{O}, \mathrm{ZrP}\right)$, zirconium sulphophenylphosphates and heteropolyacids. Furthermore, ionic liquids or phosphoric acid can be a substitute for water due to less volatile properties while under dehydrating ambiance in order to sustain high proton conductivity, for example, $10^{-2} \mathrm{~S} \cdot \mathrm{cm}^{-1}$ [38]. However, Nafion membrane is very expensive with the addition of not having adequate conductivity at a higher temperature of $90^{\circ} \mathrm{C}$ and near anhydrous condition. It is also not environmentally friendly due to the usage of many chemicals in its fabrication, utilization, and discarding processes [32]. In the DMFC system, the Nafion membrane or perfluorinated PEM cannot be directly used due to the high crossover of methanol that can shorten the lifetime and performance of the fuel cells. The high methanol crossover can be explained by the large channel related to the molecular structure that consists of a large ion group [4].

Currently, Nafion and Nafion-based membrane are the most popular and widely used membranes for applications in proton exchange membrane fuel cell, direct methanol fuel cell, and electrolyzers. It has good proton conductivity and fair thermal stability for operating in temperatures below $80^{\circ} \mathrm{C}$. However, Nafion is very costly and permeable to fuel, thus allowing diffusion of anolyte to catholyte. In addition, Nafion also loses its good proton conductivity properties at operating temperatures beyond $100^{\circ} \mathrm{C}$ [27].

\subsubsection{Polybenzimidazole}

Polybenzimidazole (PBI) refers to multiple units of benzimidazole in the structure of aromatic heterocyclic polymers. PBI has a few advantages as compared to Nafion membrane including good tensile strength, fair chemical stability, and exclusive affinity with polyaryletherketone and some other polymers. Figure 2 presents the synthesis of PBI polymer.

Although Nafion membrane is very good for processes that operate at temperatures from 20 to $80^{\circ} \mathrm{C}$, it is not suitable for high-temperature (HT) applications above $100^{\circ} \mathrm{C}$ due to poor mechanical stability and the significant decrease of proton conductivity [40]. Polybenzimidazole (PBI) was first used by Wainright in 1995 for high-temperature-polymer electrolyte membrane 
(HT-PEM) at $150^{\circ} \mathrm{C}$ and is a very suitable candidate for any process temperature ranging from 120 to $200^{\circ} \mathrm{C}[35,41]$.

However, pristine PBI has very low conductivity when compared to Nafion, which makes it unsuitable as a replacement for Nafion. Researches to improve the proton conductivity of pristine PBI have been carried out by treating the PBI with many inorganic acids via PBI composite membrane synthesis. Sulfuric acid $\left(\mathrm{H}_{2} \mathrm{SO}_{4}\right)$ and phosphoric acid $\left(\mathrm{H}_{3} \mathrm{PO}_{4}\right)$ act as a synergistic effect of contributor and acceptor in transferring the proton, thus allowing for proton transport through the membrane. Phosphoric acid $\left(\mathrm{H}_{3} \mathrm{PO}_{4}\right)$ is more favorable when compared to sulfuric acid $\left(\mathrm{H}_{2} \mathrm{SO}_{4}\right)$ due to its superiority with process temperatures greater than $150^{\circ} \mathrm{C}$ in terms of mechanical strength, improved proton conductivity, and thermal durability [35, 42].

When PBI membrane was doped with phosphoric acid $\left(\mathrm{H}_{3} \mathrm{PO}_{4}\right)$, its properties improved including low gas permeability, low methanol vapor crossover, and it did not need any humidification. Despite having the advantage of operating at a higher temperature range above $100^{\circ} \mathrm{C}$, the doping process is necessary to reinforce the mechanical stability of the membrane due to standard PBI-like Celazole that has a low-to-medium linear molecular weight with poor mechanical stability and poor oxidative resistance. Following are the advantages of HT-PEM-FC that operates above $100^{\circ} \mathrm{C}$ : ability to use less expensive nonnoble catalyst like cobalt and iron, improved heat rejection rate, enhanced water management, more robust to impurities, and better electrode kinetics [41].

Hybrid membrane from PBI can be prepared by the addition of inorganic fillers such as silicates, titanium dioxide $\left(\mathrm{TiO}_{2}\right)$, zirconium dioxide $\left(\mathrm{ZrO}_{2}\right)$, heteropolyacids (HPA), and carbon nanotubes (CNT) [22]. Barium zirconium oxide $\left(\mathrm{BaZrO}_{3}\right)$ was fabricated as a composite membrane from PBI base according to Hooshyari et al. [43] who also researched on the nanocomposite $\mathrm{PEM}-\mathrm{ZrO}_{2}$ nanocluster that was mixed into a solution cast of 2,6-pyridine polybenzimidazole (2,6,Py-PBI) and doped with phosphoric acid with variations from 0 to $10 \mathrm{wt} \%$ of $\mathrm{ZrO}_{2}$ nanocluster [44].

There are few approaches to enhance the properties of PBI-doped $\mathrm{H}_{3} \mathrm{PO}_{4}$ membrane, which includes a method of preparing ion cross-linked structures such as a mixture of PBI with sulfonated polyether ether ketone (SPEEK), sulfonated polysulfone, or sulfonated partially fluorinated arylene polyether [38]). In addition, improved PBI-doped phosphoric acid membrane can be synthesized by covalently cross-linked structure or composite/hybrid PBI membrane. In PBI/PA, the proton conductivity is strongly dependent on the acid doping level, which is defined as the number of PA molecules per repeating units of the polymer.

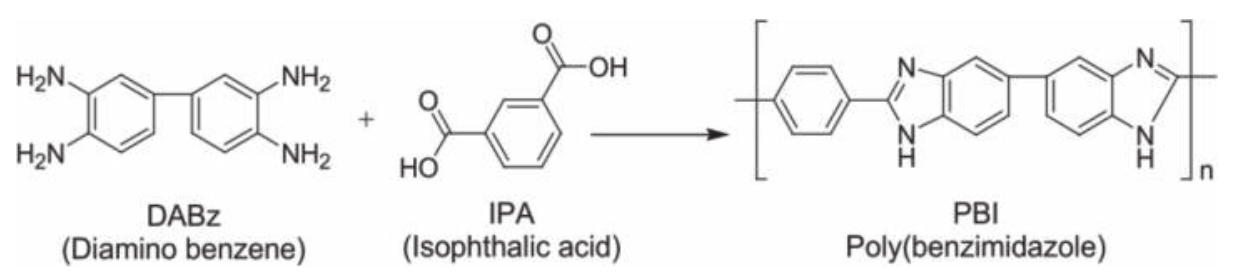

Figure 2. Synthesis of poly(benzimidazole) (PBI) [39]. 
PBI-based PEM-FC cathode is 70-fold more invulnerable to sulfur content in the air as compared to Nafion ${ }^{\circledR}$-based PEM-FC cathodes [40]. It is also noted that acid doping in PBI shows a significant effect in the membrane thermal stability and proton conductivities [45]. The proton conductivities of acid-doped PBI membranes were also dependent to the doped acids in the order of $\mathrm{H}_{2} \mathrm{SO}_{4}>\mathrm{H}_{3} \mathrm{PO}_{4}>\mathrm{HClO}_{4}>\mathrm{HNO}_{3}>\mathrm{HCl}[45,46]$. Similarly, Oono et al. [47] studied the influence of the phosphoric acid doping level in a PBI membrane by means of immersing the PBI membrane in $85 \%$ phosphoric acid solution for $500 \mathrm{~min}$ at $20^{\circ} \mathrm{C}$ and $80 \mathrm{~min}$ at 40 and $60^{\circ} \mathrm{C}$. Sulfonated PBI showed higher proton conductivity as compared to pristine PBI membrane due to more active acid sites. PBI blending with Nafion, sulfonated polyether, and polyphosphazene were studied to investigate the effect on membrane stability and less permeable to methanol crossover. Moreover, the addition of inorganic fillers enhanced the properties of proton conductivities and physical strength of the modified membrane. However, doping decreased the proton conductivities, but this could be controlled by introducing sulfonated material as reinforcements.

There are numerous methods that have been implemented to enhance the conductivity and stability of PBI membranes, which include membrane fabrication technique for optimization, polymer backbone crosslinking, polymer blending, and creating composite membrane by the introduction of many kinds of organic acids. Factors influencing the proton conductivity of PA-doped PBI and PBI composite membrane are process temperature, acid doping level (ADL), and relative humidity (RH). This was found in PA-doped PBI that had a 5.6 doping level (mole number of $\mathrm{H}_{3} \mathrm{PO}_{4}$ per repeat unit of $\mathrm{PBI}$ ) with a conductivity of $6.8 \times 10^{-2} \mathrm{~S} \mathrm{~cm}^{-1}$ and process conditions at $200^{\circ} \mathrm{C}$ and $5 \% \mathrm{RH}$. Moreover, under the similar setting, the PBI composite membrane with $15 \mathrm{wt} \%$ of Zirconium Phosphate $(\mathrm{ZrP})$ reported a greater conductivity of $9.6 \times 10^{-2} \mathrm{~S} \mathrm{~cm}^{-1}$ [42]. Nonetheless, the PBI-based membrane still has the disadvantage of poor mechanical properties after doping with a high concentration of acid and poor ability to withstand the long duration of testing [44].

The mechanism in proton conductivity for PA-doped PBI membrane enables PA to transfer the proton contrary to water which helps to increase the temperature span of fuel cell membranes. This is not possible for membranes like Nafion or other sulfonated membranes in an anhydrous condition, which relies heavily on water for proton $\mathrm{H}^{+}$movement. However, there is the possibility of PA being detached from the PA-doped PBI membrane if the temperature of the system decreases below $100^{\circ} \mathrm{C}$ due to water condensation that is forced out of the PA from the membrane. Apart from that, the detached PA can lead to corrosion in the fuel cell system of PA-doped PBI in fuel cell that can chemically deteriorate at operation temperature of $150-200^{\circ} \mathrm{C}$, which is crucial in diminishing the poisoning effect to the anode catalyst due to carbon monoxide generation [48]. Titania, $\mathrm{TiO}_{2}$ and zirconia, and $\mathrm{ZrO}_{2}$, which are categorized as inorganic fillers can be integrated into the modification of composite PA-doped PBIbased membrane by enhancing the hydromechanical characteristics. This is achieved due to improvement in the proton conductivity and stability of PBI-based membrane in PA-doped medium [44]. Summary of PBI improvement techniques from several types of research is illustrated in Table 2.

Previous studies of PBI polymer have demonstrated that PBI derivatives, the 2OH-PBI polymer (dihydroxy function groups), have formed the phosphate linkages between the hydroxyl 


\begin{tabular}{|c|c|c|c|}
\hline No. & Methods & References & Remarks \\
\hline 1. & $\begin{array}{l}\text { Optimization of membrane fabrication } \\
\text { techniques }\end{array}$ & {$[35,49]$} & \multirow{4}{*}{$\begin{array}{l}\text { Improvements were found limited demonstrating } \\
\text { weakness in mechanical strength when highly loaded } \\
\text { with acid and poor endurance when tested for a long } \\
\text { term [50] }\end{array}$} \\
\hline 2. & Crosslinking of polymer backbone & [51-55] & \\
\hline 3. & Blending with other polymers & {$[56-58]$} & \\
\hline 4. & $\begin{array}{l}\text { Forming a composite structure by } \\
\text { incorporation of various inorganic } \\
\text { acids }\end{array}$ & {$[22,26,42,59]$} & \\
\hline 5. & $\begin{array}{l}\text { Designing composite PA doped } \\
\text { PBI-based membranes using ceramic } \\
\text { nanoscale and mesoscale fillers such as } \\
\text { Titania and Zirconia }\end{array}$ & {$[60,61]$} & $\begin{array}{l}\text { Nanoscale } \mathrm{ZrO}_{2} \text { filler and the accompanied membrane } \\
\text { casting is challenged by agglomeration and } \\
\text { precipitation [62] }\end{array}$ \\
\hline 6. & $\begin{array}{l}\text { Adding more nitrogen atoms to the } \\
\text { polymer molecule structure to enhance } \\
\text { acid retention. }\end{array}$ & {$[60]$} & $\begin{array}{l}\text { Development of pyridine-polybenzimidazole } \\
\text { (Py-PBI), which provides an additional pyridine ring } \\
\text { capable of boosting the interaction with PA }[60,63-65\end{array}$ \\
\hline
\end{tabular}

Table 2. Summary of PBI improvement techniques.

groups of the PBI backbone during polymerization in poly (phosphoric acid) in the crosslinking process. However, the increase in proton conductivity is not translated into better performance of fuel cell. Instead, Pt alloy that has been used as catalysts turned out to give better results, which was $0.49 \mathrm{~A} / \mathrm{cm}^{2}$ at $0.6 \mathrm{~V}$ and $0.69 \mathrm{~V}$ at $0.2 \mathrm{~A} / \mathrm{cm}^{2}$ with operation temperatures at $180^{\circ} \mathrm{C}$ and pressure of $1 \mathrm{~atm}$ in $\mathrm{H}_{2} /$ air environment [66].

\subsubsection{Polyether ether ketone}

Today, Victrex is the leading manufacturer of PEEK polymer in the world. The sulfonation process for its PEEK membrane is introduced using sulfonic acid groups $\left(\mathrm{SO}_{3} \mathrm{H}\right)$ via alteration or polymerization of sulfonated monomers onto the backbone structure of the polymer. The hydrophilic nature of the PEEK polymer is developed from the accumulation of sulfonic acid groups. It has been reported that the membranes developed the carrier for proton charge as the consequences of the segregation of the sulfonic acid groups and proton conductivity with the help of water movement in PEEK hydrated state [27]. This is supported by the fact that polymer with aromatic rings like polyether ether ketone (PEEK), polybenzimidazoles (PBI), polyoxadiazole, polysulfone (PSf), and polyimides can contribute to cheaper production cost and deliver sufficient physicochemical properties [67].

To date, previous studies have shown that alteration of PEEK polymer properties can replace Nafion membrane in PEM-FC and DEMFC systems. Significant mechanisms are critically used to prepare the PEM from PEEK like PEEK electrophilic sulfonation (S-PEEK), S-PEEK and nonfunctional polymers blending, and S-PEEK heteropolycompounds with polyetherimide doping with organic acids [27]. Therefore, it is crucial to regulate the degree of sulfonation (DS) as it is affecting the thermochemical stability of PEEK membranes by keeping the DS low [68]. It has been reported that the workability of proton exchange membranes 
from sulfonated polyether ether ketone (SPEEK) are strengthened by unaltered silica $\left(\mathrm{SiO}_{2}\right)$ and altered silica $\left(\mathrm{SiO}_{2}-\mathrm{SO}_{3} \mathrm{H}\right)$ nanoparticles. The characterization of sulfonated membranes includes the degree of sulfonation (DS), water uptake, and thermostability properties. The $\mathrm{SiO}_{2}$ fusion elevates the degree of hydrophilic tendency, hence admitting a higher degree of water retention that promotes better route for proton transfer. However, we can observe that there is a decrement of the proton conductivity. The steady synergy of $-\mathrm{SO}_{3} \mathrm{H} /-\mathrm{SO}_{3} \mathrm{H}$ within $\mathrm{SiO}_{2}-\mathrm{SO}_{3} \mathrm{H}$ and SPEEK chains results in ion cross-linked membrane framework which balances the reduction in proton conductivity. The SPEEK/SiO $2-\mathrm{SO}_{3} \mathrm{H}$ membrane with nanoparticles fillers has the ability to function as a competent PEM from the performance study conducted for fuel cell application [69].

\section{Electrolyzer technologies}

The chemical reaction equation for an electrolyzer is presented in Eq. (1):

$$
2 \mathrm{CuCl}(\mathrm{s})+2 \mathrm{HCl}(\mathrm{aq}) \rightarrow \mathrm{H}_{2}(\mathrm{~g})+2 \mathrm{CuCl}_{2}(\mathrm{aq})
$$

The Atomic Energy of Canada Limited (AECL) has succeeded in generating hydrogen from the above step using $\mathrm{CuCl} / \mathrm{HCl}$ electrolyzer and suggesting an alteration to the existing $\mathrm{CuCl}$ cycle [70, 71]. The operating parameters, appropriate membrane selection, and electrochemical cell's scheme are important factors to be tackled in order to have a functional electrolyzer. AECL has tested and determined that the $\mathrm{CuCl}$ electrolyzer needs to have these characteristics [72]:

i. Optimum pressure 24 bar, temperature range $70-80^{\circ} \mathrm{C}$

ii. $0.1 \mathrm{~A} \mathrm{~cm}^{-2}$ of current density

iii. $0.6-0.7 \mathrm{~V}$ range of cell voltage

iv. $1.23 \mathrm{~V}$ of reversible cell potential

v. $75 \%$ of potential conversion

vi. $0.5 \mathrm{M} \mathrm{CuCl}$ and $11 \mathrm{M} \mathrm{HCl}$ as recommended concentration for operation

vii. $\Delta \mathrm{H}=93.76 \mathrm{~kJ} / \mathrm{mol}[71]$

Research conducted by Naterer et al. confirmed that the $\mathrm{CuCl} / \mathrm{HCl}$ electrolysis reaction rate enhances with the increment of reaction temperature and the concentration of $\mathrm{CuCl}$ [72] and greater current density at $80^{\circ} \mathrm{C}$ when compared to $25^{\circ} \mathrm{C}$ for the same cell voltage [17]. The schematic diagram of proton exchange membrane (PEM) water electrolysis cells is presented in Figure 3. The solid polymer electrolyte that conducts proton ion is sandwiched between two electrodes to construct a membrane electrode assembly (MEA). The MEA is submerged in pure water $(18 \mu \mathrm{cm})$ and the proton movement stays within the membrane's boundary. 


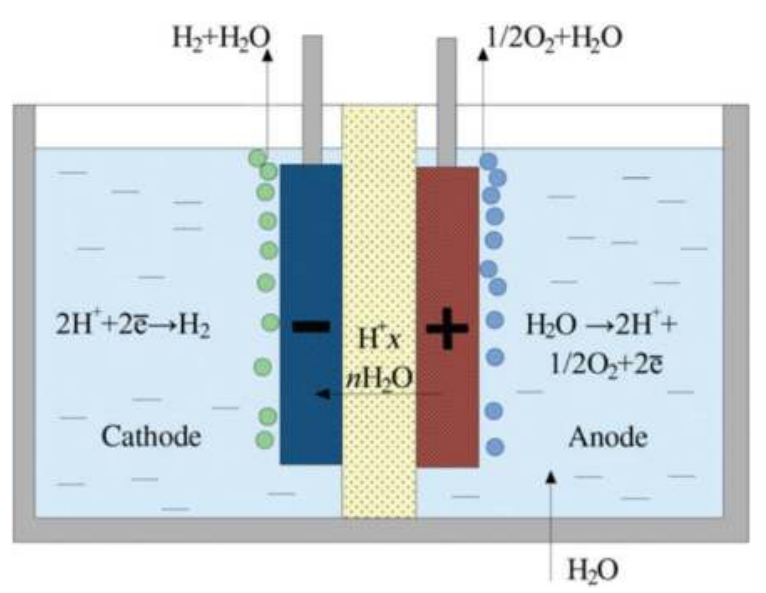

Figure 3. Schematic diagram of PEM electrolysis cell [33].

The efficiency of a PEM cell is dependent on the current density during operation. While a higher current density is crucial to cut down the start-up cost, a lower current density is needed to cut down the cost of operation. Both factors have to be taken into consideration [33]. Different types of electrolytes can be deployed in an EL cell: an alkaline electrolysis (AEL) cell works with a basic liquid electrolyte. In a proton exchange membrane (PEM) EL cell, an acidic ionomer-a process often called solid polymer electrolysis (SPE) - is used, and a high-temperature (HT) EL cell has a solid oxide as the electrolyte. The schematic diagram of the alkaline electrolysis cell is presented in Figure 4.

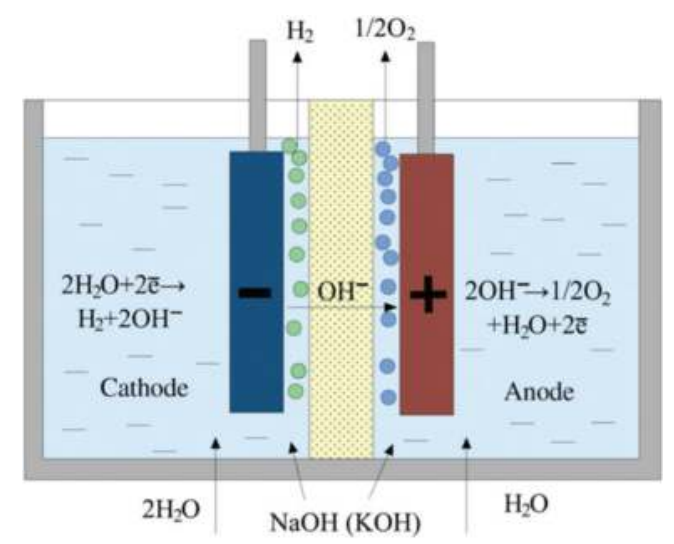

Figure 4. Schematic diagram of the alkaline electrolysis cell [34]. 


\begin{tabular}{|c|c|c|}
\hline Technology & Advantages & Disadvantages \\
\hline \multirow[t]{7}{*}{ Alkaline electrolysis } & Technology: oldest and well established & Current density: low \\
\hline & Cost: cheapest and effective & Degree of purity: low (crossover of gases) \\
\hline & Catalyst type: Noble & Electrolyte: liquid and corrosive \\
\hline & Durability: Long term & Dynamics: low dynamic operation \\
\hline & Stacks: MW range & Load range: low for partial load \\
\hline & Efficiency: $70 \%$ & \multirow[t]{2}{*}{ Pressure: Low operational pressure } \\
\hline & Commercialized & \\
\hline \multirow[t]{8}{*}{ PEM electrolysis } & Current density: high & Technology: new and partially establish \\
\hline & Voltage efficiency: high & Cost: high cost of components \\
\hline & Load range: Good partial load range & Catalyst: noble catalyst \\
\hline & System design: compact & Corrosion: acidic environment \\
\hline & Degree of purity: high gas purity & Durability: comparatively low \\
\hline & Dynamics: high dynamics operation & Stack: Below MW range \\
\hline & \multirow[t]{2}{*}{ Response: rapid system response } & Membrane: limited and costly \\
\hline & & Commercialization in near term \\
\hline \multirow{5}{*}{$\begin{array}{l}\text { High-temperature steam } \\
\text { electrolysis }\end{array}$} & Efficiency: $100 \%$ & Technology: in laboratory phase \\
\hline & \multirow{2}{*}{$\begin{array}{l}\text { Thermal neutral efficiency }>100 \% \text { with } \\
\text { hot steam }\end{array}$} & Durability: low due to high heat, ceramics \\
\hline & & \multirow[t]{3}{*}{ System design: bulk system design } \\
\hline & Catalyst: Nonnoble & \\
\hline & Pressure: High-pressure operation & \\
\hline
\end{tabular}

Table 3. A comparison between alkaline, PEM, and high-temperature electrolysis [73-75].

To ensure a sufficiently high ionic conductivity, every electrolyte requires minimum temperatures. The upper temperature limit is determined mostly by the stability of the cell materials and components. More details are provided in later in this chapter.

Currently, three most used electrolysis technologies are being used. A comparison between alkaline, PEM, and high-temperature electrolysis is presented in Table 3.

\section{Conclusion}

In this chapter, hydrogen production from membrane electrolysis is discussed in detail. Hydrogen production from membrane water splitting technologies possesses great potential as a sustainable hydrogen source. Previous research focused mainly on Nafion-based membrane, but with the advancement in the research, a better and cheaper membrane can be used without compromising on the output of hydrogen production. Composite membrane provides better performance in terms of durability, heat resistance, hydrogen production, and purity. 


\section{Acknowledgements}

The authors would like to express appreciation for the financial support provided by the Ministry of Higher Education Malaysia under the Universiti Putra Malaysia project number 9452000 GP-IPM Putra Grant and Universiti Teknologi Malaysia project number 03G10 Flagship Research University Grant.

\section{Author details}

Mohd Fadhzir Ahmad Kamaroddin ${ }^{1,2}$, Nordin Sablii ${ }^{2 *}$ and Tuan Amran Tuan Abdullah²

*Address all correspondence to: nordin_sab@upm.edu.my

1 Universiti Putra Malaysia, Selangor, Malaysia

2 Universiti Teknologi Malaysia, Johor, Malaysia

\section{References}

[1] Oh TH, Hasanuzzaman M, Selvaraj J, Teo SC, Chua SC. Energy policy and alternative energy in Malaysia: Issues and challenges for sustainable growth - An update. Renewable and Sustainable Energy Reviews. 2018;81(P2):3021-3031

[2] Wang Z, Roberts RR, Naterer GF, Gabriel KS. Comparison of thermochemical, electrolytic, photoelectrolytic and photochemical solar-to-hydrogen production technologies. International Journal of Hydrogen Energy. 2012:16287-16301

[3] Apak S, Atay E, Tuncer G. Renewable hydrogen energy regulations, codes and standards: Challenges faced by an EU candidate country. International Journal of Hydrogen Energy. 2012;37(7):5481-5497

[4] Shi D, Guo Z, Bedford N, Shi D, Guo Z, Bedford N. 10-Nanoenergy materials. In: Nanomaterials and Devices. 2015. pp. 255-291

[5] Dincer I. Green methods for hydrogen production. International Journal of Hydrogen Energy. 2012;37(2):1954-1971

[6] Razykov TM, Ferekides CS, Morel D, Stefanakos E, Ullal HS, Upadhyaya HM. Solar photovoltaic electricity: Current status and future prospects. Solar Energy. 2011;85 (8):1580-1608

[7] Mekhilef S, Safari A, Mustaffa WES, Saidur R, Omar R, Younis MAA. Solar energy in Malaysia: Current state and prospects. Renewable and Sustainable Energy Reviews. 2012;16(1):386-396. Available from: http://www.sciencedirect.com/science/article/pii/ S1364032111004138 
[8] Timilsina GR, Kurdgelashvili L, Narbel PA. Solar energy: Markets, economics and policies. Renewable and Sustainable Energy Reviews. 2012;16(1):449-465

[9] Reichelstein S, Yorston M. The prospects for cost competitive solar PV power. Energy Policy. 2013;55:117-127

[10] Nicoletti G, Arcuri N, Nicoletti G, Bruno R. A technical and environmental comparison between hydrogen and some fossil fuels. Energy Conversion and Management. 2015;89:205-213

[11] Ball M, Weeda M. The hydrogen economy - Vision or reality? International Journal of Hydrogen Energy. 2015;40(25):7903-7919. DOI: 10.1016/j.ijhydene.2015.04.032

[12] Mazloomi K, Gomes C. Hydrogen as an energy carrier: Prospects and challenges. Renewable and Sustainable Energy Reviews. 2012;16:3024-3033

[13] Dutta S. A review on production, storage of hydrogen and its utilization as an energy resource. Journal of Industrial and Engineering Chemistry. 2014;20:1148-1156

[14] Stiegel GJ, Ramezan M. Hydrogen from coal gasification: An economical pathway to a sustainable energy future. International Journal of Coal Geology. 2006;65(3-4):173-190

[15] Zhang F, Zhao P, Niu M, Maddy J. The survey of key technologies in hydrogen energy storage. International Journal of Hydrogen Energy. 2016;41(33):14535-14552

[16] Smolinka T, Ojong ET. Chapter 8 - Hydrogen production from renewable energiesElectrolyzer technologies. In: Electrochemical Energy Storage for Renewable Sources and Grid Balancing. 2015. pp. 103-128

[17] Naterer G, Suppiah S, Lewis M, Gabriel K, Dincer I, Rosen MA, et al. Recent Canadian advances in nuclear-based hydrogen production and the thermochemical $\mathrm{Cu}-\mathrm{Cl}$ cycle. International Journal of Hydrogen Energy. 2009;34(7):2901-2917

[18] Rashid MM, Mesfer MK, Al Naseem H, Danish M. Hydrogen production by water electrolysis: A review of alkaline water electrolysis, PEM water electrolysis and high temperature water electrolysis. International Journal of Engineering and Advanced Technology. 2015;3:2249-8958

[19] Aghahosseini S, Dincer I, Naterer GF. Linear sweep voltammetry measurements and factorial design model of hydrogen production by $\mathrm{HCl} / \mathrm{CuCl}$ electrolysis. International Journal of Hydrogen Energy. 2013;38(29):12704-12717

[20] Lewis MA, Masin JG, O'Hare PA. Evaluation of alternative thermochemical cycles, Part I: The methodology. International Journal of Hydrogen Energy. 2009;34(9):4115-4124

[21] Ran J, Wu L, He Y, Yang Z, Wang Y, Jiang C, et al. Ion exchange membranes: New developments and applications. Journal of Membrane Science. 2016;522:267-291 Available from: http://linkinghub.elsevier.com/retrieve/pii/S0376738816307980

[22] Mishra AK, Bose S, Kuila T, Kim NH, Lee JH. Silicate-based polymer-nanocomposite membranes for polymer electrolyte membrane fuel cells. Progress in Polymer Science. 2012;37(6):842-869 
[23] Labalme E, David G, Souquet J, Buvat P, Bigarre J. Use of a new crosslinking method to obtain semi-IPN membranes with phosphonic acid groups for a PEMFC application. Journal of Materials Chemistry A. 2014;2(25):9792 Available from: http://xlink.rsc. org/?DOI=c4ta01472c

[24] Shao Z, Sannigrahi A, Jannasch P. Poly(tetrafluorostyrenephosphonic acid)-polysulfone block copolymers and membranes. Journal of Polymer Science Part A: Polymer Chemistry. 2013;51(21):4657-4666

[25] Simon S, Zhou F, Liso V, Lennart S, Rabjerg J, Thomas S, et al. A comprehensive review of PBI-based high temperature PEM fuel cells. International Journal of Hydrogen Energy. 2016:1-35

[26] Seo K, Seo J, Nam K-H, Han H. Polybenzimidazole/inorganic composite membrane with advanced performance for high temperature polymer electrolyte membrane fuel cells. Polymer Composites [Internet]. 2017;38(1):87-95. DOI: 10.1002/pc.23563

[27] Iulianelli A, Basile A. Sulfonated PEEK-based polymers in PEMFC and DMFC applications: A review. International Journal of Hydrogen Energy. 2012;37(20):15241-15255

[28] Abouzari-Lotf E, Nasef MM, Ghassemi H, Zakeri M, Ahmad A, Abdollahi Y. Improved methanol barrier property of Nafion hybrid membrane by incorporating nanofibrous interlayer self-immobilized with high level of phosphotungstic acid. ACS Applied Materials \& Interfaces. 2015;7(31):17008-17015

[29] Kim DJ, HChoi DH, Park CH, Sam SY. Characterization of the sulfonated PEEK/sulfonated nanoparticles composite membrane for the fuel cell application. 2016;41:5793-5802

[30] Seetharaman S, Raghu SC, Mahabadi KA. Enhancement of current density using effective membranes electrode assemblies for water electrolyser system. Journal of Energy Chemistry. 2016;25(1):77-84

[31] Ahmad H, Kamarudin SK, Hasran UA, Daud WRW. Overview of hybrid membranes for direct-methanol fuel-cell applications. International Journal of Hydrogen Energy. 2010;35(5):2160-2175

[32] Di Noto V, Zawodzinski TA, Herring AM, Giffin GA, Negro E, Lavina S. Polymer electrolytes for a hydrogen economy. International Journal of Hydrogen Energy. 2012;37(7):6120-6131

[33] Millet P, Grigoriev S. Water electrolysis technologies. In: Renewable Hydrogen Technologies: Production, Purification, Storage, Applications and Safety. 2013. pp. 19-41

[34] Millet P, Grigoriev S. Water electrolysis technologies. Renewable Hydrogen Technologies: Production, Purification, Storage, Applications and Safety. 2013. pp. 19-41

[35] Li Q, Jensen JO, Savinell RF, Bjerrum NJ. High temperature proton exchange membranes based on polybenzimidazoles for fuel cells. Progress in Polymer Science. 2009;34(5):449-477

[36] Kraytsberg A, Ein-Eli Y. Review of advanced materials for proton exchange membrane fuel cells. Energy \& Fuels [Internet]. 2014;28(12):7303-7330. DOI: 10.1021/ef501977k 
[37] Abdo N, Bradley Easton E. Nafion/polyaniline composite membranes for hydrogen production in the $\mathrm{Cu}-\mathrm{Cl}$ thermochemical cycle. International Journal of Hydrogen Energy. 2016;41(19):7892-7903

[38] Aili D, Hansen MK, Pan C, Li Q, Christensen E, Jensen JO, et al. Phosphoric acid doped membranes based on Nafion ${ }^{\circledR}$, PBI and their blends-Membrane preparation, characterization and steam electrolysis testing. International Journal of Hydrogen Energy. 2011;36(12):6985-6993

[39] Hwang K, Kim JH, Kim SY, Byun H. Preparation of polybenzimidazole-based membranes and their potential applications in the fuel cell system. Energies. 2014;7(3):1721-1732

[40] Garsany Y, Gould BD, Baturina OA, Swider-Lyons KE. Comparison of the sulfur poisoning of PBI and Nafion PEMFC cathodes. Electrochemical and Solid-State Letters. 2009;12(9):B138-B140 Available from: http://link.aip.org/link/ESLEF6/v12/i9/pB138/ s1\&Agg=doi\%5Cnhttp://esl.ecsdl.org/cgi/doi/10.1149/1.3168516

[41] Araya SS, Zhou F, Liso V, Sahlin SL, Vang JR, Thomas S. A comprehensive review of PBI-based high temperature PEM fuel cells. International Journal of Hydrogen Energy. 2016;41(46):21310-21344

[42] He R, Li Q, Xiao G, Bjerrum NJ. Proton conductivity of phosphoric acid doped polybenzimidazole and its composites with inorganic proton conductors. Journal of Membrane Science. 2003;226(1-2):169-184

[43] Hooshyari K, Javanbakht M, Shabanikia A, Enhessari M. Fabrication $\mathrm{BaZrO}_{3} / \mathrm{PBI}$-based nanocomposite as a new proton conducting membrane for high temperature proton exchange membrane fuel cells. Journal of Power Sources. 2015;276:62-72. DOI: 10.1016/j. jpowsour.2014.11.083

[44] Nasef MM, Fujigaya T, Abouzari-Lotf E, Nakashima N, Yang Z. Enhancement of performance of pyridine modified polybenzimidazole fuel cell membranes using zirconium oxide nanoclusters and optimized phosphoric acid doping level. International Journal of Hydrogen Energy. 2016;41(16):6842-6854

[45] Suryani, Liu Y-L. Preparation and properties of nanocomposite membranes of polybenzimidazole/sulfonated silica nanoparticles for proton exchange membranes. Journal of Membrane Science. 2009;332(1-2):121-128

[46] Xing B, Savadogo O. The effect of acid doping on the conductivity of polybenzimidazole (PBI). Journal of New Materials for Electrochemical Systems. 1999;2(2):95-101

[47] Oono Y, Sounai A, Hori M. Influence of the phosphoric acid-doping level in a polybenzimidazole membrane on the cell performance of high-temperature proton exchange membrane fuel cells. Journal of Power Sources. 2009;189(2):943-949

[48] Mack F, Aniol K, Ellwein C, Kerres J, Zeis R. Novel phosphoric acid-doped PBI-blends as membranes for high-temperature PEM fuel cells. Journal of Materials Chemistry A [Internet]. 2015;3(20):10864-10874 Available from: http://pubs.rsc.org/en/Content/ ArticleLanding/2015/TA/C5TA01337B 
[49] Xiao L, Zhang H, Scanlon E, Ramanathan LS, Choe E-W, Rogers D, et al. Hightemperature polybenzimidazole fuel cell membranes via a sol-gel process. Chemistry of Materials [Internet]. 2005;17(21):5328-5333. DOI: 10.1021/cm050831

[50] Li X, Chen X, Benicewicz BC. Synthesis and properties of phenylindane-containing polybenzimidazole (PBI) for high-temperature polymer electrolyte membrane fuel cells (PEMFCs). Journal of Power Sources. 2013;243:796-804

[51] Li Q, Pan C, Jensen JO, Noye P, Bjerrum NJ. Cross-linked polybenzimidazole membranes for fuel cells. Chemistry of Materials. 2007;15(21):350-352

[52] Zhai $\mathrm{Y}$, Zhang $\mathrm{H}$, Zhang $\mathrm{Y}$, Xing D. A novel $\mathrm{H}_{3} \mathrm{PO}_{4} /$ Nafion-PBI composite membrane for enhanced durability of high temperature PEM fuel cells. Journal of Power Sources. 2007;169(2):259-264

[53] Noye P, Li Q, Pan C, Bjerrum NJ. Cross-linked polybenzimidazole membranes for high temperature proton exchange membrane fuel cells with dichloromethyl phosphinic acid as a cross-linker. Polymers for Advanced Technologies. 2008;19:1270-1275

[54] XU N, GUO X, FANG J, XU H, YIN J. Synthesis of novel Polybenzimidazoles with pendant amino groups and the formation of their crosslinked membranes for medium temperature fuel cell applications. Journal of Polymer Science Part A: Polymer Chemistry. 2009;47:6992-7002

[55] Zhai $\mathrm{Y}$, Zhang $\mathrm{H}$, Xing D, Shao ZG. The stability of $\mathrm{Pt} / \mathrm{C}$ catalyst in $\mathrm{H}_{3} \mathrm{PO}_{4} / \mathrm{PBI} \mathrm{PEMFC}$ during high temperature life test. Journal of Power Sources. 2007;164(1):126-133

[56] Arunbabu D, Sannigrahi A, Jana T. Blends of polybenzimidazole and poly(vinylidene fluoride) for use in a fuel cell. The Journal of Physical Chemistry. B. 2008;112(17):5305-5310

[57] Li QF, Rudbeck HC, Chromik A, Jensen JO, Pan C, Steenberg T, et al. Properties, degradation and high temperature fuel cell test of different types of PBI and PBI blend membranes. Journal of Membrane Science. 2010;347(1-2):260-270

[58] Cho H, Hur E, Henkensmeier D, Jeong G, Cho E, Kim HJ, et al. Meta-PBI/methylated PBI-OO blend membranes for acid doped HT PEMFC. European Polymer Journal. 2014;58:135-143

[59] Staiti P, Minutoli M, Hocevar S. Membranes based on phosphotungstic acid and polybenzimidazole for fuel cell application. Journal of Power Sources. 2000;90(2):231-235

[60] Quartarone E, Magistris A, Mustarelli P, Grandi S, Carollo A, Zukowska GZ, et al. Pyridine-based PBI composite membranes for PEMFCs. Fuel Cells. 2009:349-355

[61] Di Noto V, Piga M, Giffin GA, Quartarone E, Righetti P, Mustarelli P, et al. Structureproperty interplay of proton conducting membranes based on $\mathrm{PBI} 5 \mathrm{~N}, \mathrm{SiO}_{2}-\mathrm{Im}$ and $\mathrm{H}_{3} \mathrm{PO}_{4}$ for high temperature fuel cells. Physical Chemistry Chemical Physics. 2011;13(26):1214654. Available from: http://www.ncbi.nlm.nih.gov/pubmed/21594297

[62] Quartarone E, Villa DC, Angioni S, Mustarelli P. Facile and green assembly of nanocomposite membranes for fuel cells. Chemical Communications [Internet]. 2015;51(10):19831986 Available from: http://xlink.rsc.org/?DOI=C4CC08347D 
[63] Xiao L, Zhang H, Jana T, Scanlon E, Chen R, Choe EW, et al. Synthesis and characterization of pyridine-based polybenzimidazoles for high temperature polymer electrolyte membrane fuel cell applications. Fuel Cells. 2005;5(2):287-295

[64] Sannigrahi A, Ghosh S, Maity S, Jana T. Structurally isomeric monomers directed copolymerization of polybenzimidazoles and their properties. Polymer (Guildf). 2010;51(25):5929-5941

[65] Maity S, Jana T. Soluble polybenzimidazoles for PEM: Synthesized from efficient, inexpensive, readily accessible alternative tetraamine monomer. Macromolecules. 2013;46(17):6814-6823

[66] Yu S, Benicewicz BC. Synthesis and properties of functionalized polybenzimidazoles for high-temperature PEMFCs. Macromolecules. 2009;42(22):8640-8648

[67] Jang I-Y, Kweon O-H, Kim K-E, Hwang G-J, Moon S-B, Kang A-S. Application of polysulfone (PSf)- and polyether ether ketone (PEEK)-tungstophosphoric acid (TPA) composite membranes for water electrolysis. Journal of Membrane Science. 2008;322(1):154-161

[68] Burgal JP da S. Development of poly (ether ether ketone) nanofiltration membranes for organic solvent nanofiltration in continuous flow systems [A Thesis Submitt Degree Dr Philos Imp Coll London Diploma Imp Coll London]. 2016

[69] Unnikrishnan L, Mohanty S, Nayak SK. Proton exchange membranes from sulfonated poly(ether ether ketone) reinforced with silica nanoparticles. High Performance Polymers. 2013;25(7):854-867. Available from:. DOI: http://hip.sagepub.com/cgi/ doi/10.1177/0954008313487392

[70] Naterer GF, Suppiah S, Stolberg L, Lewis M, Wang Z, Daggupati V, et al. Canada's program on nuclear hydrogen production and the thermochemical $\mathrm{Cu}-\mathrm{Cl}$ cycle. International Journal of Hydrogen Energy. 2010;35(20):10905-10926

[71] Ferrandon MS, Lewis MA, Alvarez F, Shafirovich E. Hydrolysis of $\mathrm{CuCl}_{2}$ in the $\mathrm{Cu}-\mathrm{Cl}$ thermochemical cycle for hydrogen production: Experimental studies using a spray reactor with an ultrasonic atomizer. International Journal of Hydrogen Energy. 2010;35(5):1895-1904

[72] Naterer GF. Recent Canadian advances in the thermochemical $\mathrm{Cu}-\mathrm{Cl}$ cycle for nuclear hydrogen production. In: Fourth Information Exchange Meeting; April 2009. 2010. pp. $14-16$

[73] Holladay JD, Hu J, King DL, Wang Y. An overview of hydrogen production technologies. Catalysis Today. 2009;139(4):244-260

[74] Carmo M, Fritz DL, Mergel J, Stolten D. A comprehensive review on PEM water electrolysis. International Journal of Hydrogen Energy. 2013;38:4901-4934

[75] Zeng K, Zhang D. Recent progress in alkaline water electrolysis for hydrogen production and applications. Progress in Energy and Combustion Science. 2010;36(3):307-326 
